\title{
Study of Urban Sprawl and its Social and Environmental Impacts on Urban Society in Latifabad Town, Hyderabad, Pakistan
}

\section{Saima Allah Yar*}

Centre of Excellence in Arts and Design, Mehran University of Engineering and Technology (MUET) Jamshoro, Pakistan

\begin{abstract}
Urban sprawl expansion is becoming a serious problem of many urban areas due to not much a picture of sprawl in priority, urban areas lack the infra structure and basic facilities like treated water supply, electricity, sanitation services. By the year 2016, Latifabad town accommodates 0.7 millions, which was essentially proposed for 60,000 people. Some of the problems of Latifabad town include excessive traffic congestion; pollution, increment infrastructure costs for community services; fragmentation of housing with low density areas and increase in energy consumption that causes social segregation and environmental degradation. For evaluating social and environmental impacts of sprawl, various factors were derived based on socio- environmental impacts. Quantitative results were generated using Yeh's index of satisfaction and software SPSS; which were based on questionnaires having filled by 480 occupants. The average satisfaction index from this analysis is found out to be -41.1431 , which shows a highly dissatisfaction level of residents of Latifabad town. Some smart growth opportunities can be useful in reducing the urban sprawl as to advertise the problem and raise awareness; to enforce population control, compact developments to suit their needs and enhance the use of new technology to facilitate more people to be able to work from home. The research is beneficial to reduce the sprawl as the result of this study can give the directions to local development authorities, if considered the research proposal results, the urban sprawl can be controlled at certain level.
\end{abstract}

\section{Keywords: Urbanization; Sprawl; Population; Economy}

\section{Introduction}

Urbanization is well thought-out a constructive progression associated to modernization, industrialization and universal assimilation has economically profitable to a marginal of the urban populace [1-4]. It is the substantial sign of all the productive movement that convoy rapid development [5]. It is the change from customary rural economy to new developed one [6,7]. Current developments of land uptake for built-up areas clearly disagree with the spirit and the principles of sustainability in many places in the world. Its scattered areas leave undeveloped blocks results as a pointer of environmental hazards [8,9]. Sprawl states the structure of subsidize access way together through movement to the suburbs [10]. Many urban planners consulted on the most sustainable urban structure, gave decisions in favor of sustainability measures and against urban compaction and dispersion. However, it is clear that other areas of expertise have to be involved, for improvement of urban sprawl. However; the research work can be useful for the controlling of the urban sprawl and for the making future sustainable strategies of the urban environment. The easy and most uncomplicated reason for the cities expansion is that citizens demand more areas and so they shift from city centers with limited lot sizes to urban edges and outer reaches of cities. Noise, heavy traffic, air population and lack of green space are also among major qualities in relation with urban sprawl [10]; Which causes many impacts of urban sprawl, but the major impacts are social and environmental impacts. Land cover changes are chief dynamic forces for biogeochemical set, climate transform, and production of food from local to worldwide scales [11-16]. The dynamic of built-up growth is important in the study of present-day urban studies, includes the urban sprawl as an indefinite type of growth, or expansion $[1,17]$. People living standards always have an impact on their social lives. Social factors include the demographic and cultural aspects as, education standards, socio-economic status and neighborhood class, with the interaction with the neighbors that live as close, impacts directly or indirectly in living standards. They actually play their role in increasing of public costs, because the changes in infrastructures and services are paid by contributing to the existing inhabitants that live in it. Some of the researches carried out as focused on the connection between city form and travel activities, consequently not dealing with the multifaceted links between transport-energy competence, atmospheric emission, and human contact [18-20]. However agricultural loss to city sprawl found both in developing and developed countries [21-28]. There are also many environmental impacts to the urban sprawl that can cause the serious problems, the change of cultivated lands into built up lands can make hazardous the natural habitat that live in these lands, by displace them and it can really cause a ripple in the environment. The negative collision of urban sprawl includes impacts on eco environment leads to increase in air or water pollution and conservatory gases due to increase in the consumption of fossil fuels. Due to excess use of private vehicles, pollution is also being increased; people are getting overweight and are also have to deal with disorders such as high blood pressure and other diseases that come with obesity.

Urban sprawl in Latifabad is being occurred due to different causes. Various studies have carried on finding out the factors of urban sprawl, such as, excessive traffic congestion generates a highly fragmented agricultural and natural landscape spaces reducing and removing of urban open; pollution that causes environmental degradation by encourages travel. As sprawl differentiates to other types of city expansion, such as crimes, high taxes, deficiency of infrastructures; a number of educational hubs are exists in central areas which strengthens sprawl. Land value is the other factor that has also pointed out in research study.

Latifabad unit no: 01 has become the densely-populated area, due to which the requirements of commercial areas led the conversion of residential areas into commercial strips in front of the houses. Latifabad unit no: 02 was constructed on planning, but now 10 percent of

*Corresponding author: Saima Allah Yar, Assistant Professor, Centre of Excellence in Arts and Design, Mehran University of Engineering and Technology (MUET), Jamshoro, Pakistan, Tel: +92-222110003; E-mail: arsaima.gazal@gmail.com

Received August 17, 2017; Accepted December 01, 2017; Published December 06, 2017

Citation: Yar SA (2017) Study of Urban Sprawl and its Social and Environmental Impacts on Urban Society in Latifabad Town, Hyderabad, Pakistan. J Civil Environ Eng 7: 290. doi: 10.4172/2165-784X.1000290

Copyright: $\odot 2017$ Yar SA. This is an open-access article distributed under the terms of the Creative Commons Attribution License, which permits unrestricted use, distribution, and reproduction in any medium, provided the original author and source are credited. 
infra-structure remains due to highly negligence in maintaining and restricting accompanying land. Encroachment and slums are also found. Latifabad unit no: 03 also faced the problem of densely population and spread towards the formation of slums.

Latifabad unit: 04, unit: 05 and unit: 10 exists near the river Indus channel, due to which much people avoid to accommodate themselves in these areas; although Slums are formed due to which some of its residential units have also been converted into commercial areas. Latifabad unit: 06 is a very planned and developed area, but due to densely population, encroachment and slums are also found. Latifabadunit: 07 and unit: 08 are faced by heavy encroachment and slums due to its distinction by size and disperse commercial activities. Much of the plots of Latifabad unit: 09 and Latifabad unit: 11 had been Sub divided to accommodate the maximum no: of families that makes the reasons of destroying infrastructures of both units. Latifabad unit: 12 is also highly unplanned residential area, Almost lacks the fully basic infra-structure, and some of the areas are hilly in this unit, which also discouraged the developed ratio.

Latifabad is named following the name of celebrated poet of Shah Abdul Latif Bhitai king of melody, the Indus river flows along the western boundary of the huge district. Latifabad township scheme came into existence during the year 1952 under Government: Gazette Notification. 1850 acres were acquired for Shah Latifabad Sattelite Town from Mir Muhammad Ali Retired Chief engineer Kotri Barrage; a descendent of the ruling family of talpurs. The township was originally planned in 1953-54 to accommodate 1500 plots/units triggered to accommodate a population of 60,000 people. The same area along with its latest extensions accommodates population of approximately 0.772 million people and its boundaries expanded and strained in form of slums approximately covering an area of 2975 acres. Latifabad is divided into twelve units, comprising 17 union councils. Hospital and number of schools exists in each unit all along with mixed land uses residences and very active commercial areas as shown in Figure 1.

There had been seen the sudden growth of Latifabad Township just after the developing phase by the years 1991 in an involuntary and haphazard manner typically within the town and surroundings due to have the attractions to social and environmental perspectives such as formation of proposed bungalow units, open spaces, schools, commercial markets and offices etc. Currently 0.7 million people are living in Latifabad town, which was actually designed for 60,000 people as presented in Table 1 which give the details of plots in Unit wise.

\section{Material and Methods}

In challenge to measure urban sprawl, population, availability of schools, hospitals and services, working and recreational areas, and migration rate were focused as done by Zia and Hyun [29], through which various factors are derived through above studies to analyze the growth of urban sprawl in Latifabad such as, living criteria, mode of transport vs. time factor, encroachment and parking space, fulfillment of shops and commercial areas, education level, social problems, enough space for parking, traffic noise, encroachment, parks available, conversion of parks, street furniture, health problems, usages of utilities properly, political influences and land mafia. There are certain limitations that apply to this research. The first limitation is regarding investigations relating to variable concerned with investigation on socio-environment. This research has employed a qualitative approach. Qualitative measures were done using software SPSS, which were based on questionnaires having filled by 480 occupants. The qualitative data were gathered to formulate the results based on living criteria, transportations with time factors, encroachments, availability of various services in their existing

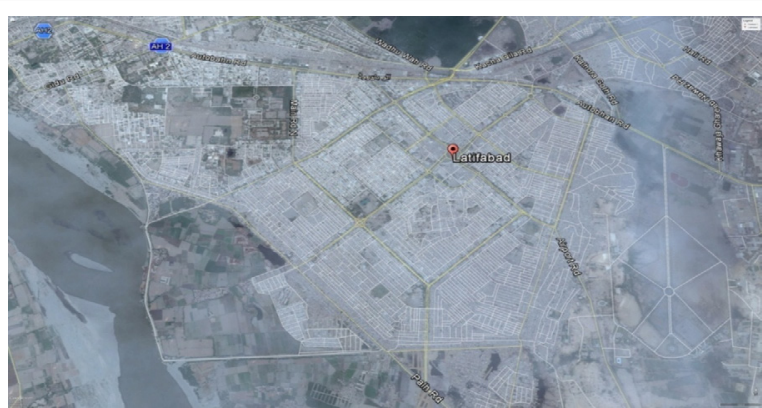

Figure 1: Latifabad image.

\begin{tabular}{|c|c|c|c|c|c|}
\hline Unit no & $\begin{array}{c}\text { Nos: of “A” } \\
\text { Type plots }\end{array}$ & $\begin{array}{c}\text { Nos: of B" } \\
\text { Type plots }\end{array}$ & $\begin{array}{c}\text { Nos: of C" } \\
\text { Type plots }\end{array}$ & $\begin{array}{c}\text { Nos: of “D” } \\
\text { Type plots }\end{array}$ & $\begin{array}{c}\text { Nos: of plots } \\
\text { Commercial }\end{array}$ \\
\hline 1 & 71 & 1 & - & - & 59 \\
\hline 11 & 86 & 184 & 8 & 95 & 59 \\
\hline 111 & 135 & 43 & 5 & - & - \\
\hline $1 V$ & 51 & 61 & - & 43 & 35 \\
\hline V & 24 & 4 & 52 & 355 & 118 \\
\hline V1 & 77 & 172 & 504 & - & 121 \\
\hline V11 & 52 & 51 & 71 & 186 & 55 \\
\hline V111 & 43 & 63 & 112 & 702 & 104 \\
\hline $1 X$ & 52 & 39 & 195 & 147 & - \\
\hline$X$ & 16 & 1 & 52 & 25 & 98 \\
\hline X1 & 26 & 20 & - & 550 & 104 \\
\hline X11 & 13 & 14 & - & 186 & - \\
\hline
\end{tabular}

Table 1: Residential and commercial units in Latifabad. (HDA, 2016).

residential units of the people lives in Latifabad, and found satisfactory and unsatisfactory indexes by using the software SPSS and Yeh's index of satisfaction.

\section{Research approach}

The qualitative approach was made to determine the capacity of Latifabad people with regards to impact in social interaction and environmental factors in order to achieve the drivers and factors for sprawl and establishing the linkages for Latifabad town. Some factors were derived to measure the level of satisfaction, as; living criteria, mode of transport by time factor, encroachment and parking space, fulfillment of shops and commercial areas, education level, social problems, enough space for parking, traffic noise, encroachment, parks available, conversion of parks, street furniture, health problems, usages of utilities properly, political influences and land mafia.

\section{Research design}

Based on above factors, the questionnaire was generated and the sample size of respondents was determined by Robert and Daryle [30]; which should be minimum 384 respondents for the current Population of Latifabadi-e 0.77 million. The questionnaire was circulated among the 480 families of Latifabad.

\section{Living criteria}

The questions were asked about the no; of family members live per unit, area of home and housing availability. The no: of factors were asked to migrate from other areas, as Latifabad had been the attraction for city dwellers since it was planned as shown in Table 2.

The survey reveals there is a less ratio of migration, $31.25 \%$ of $40-80$ sq yards are not the permanent residents, 33.19327 of the 120-150 sq yards are migrants and $27.461 \%$ of more than 200 sq yards are migrants. 
Citation: Yar SA (2017) Study of Urban Sprawl and its Social and Environmental Impacts on Urban Society in Latifabad Town, Hyderabad, Pakistan. J Civil Environ Eng 7: 290. doi: 10.4172/2165-784X.1000290

Page 3 of 5

Over all $30.688 \%$ has a migration level that shows that $69.311 \%$ of the Latifabad town is the permanent residents.

\section{Results and Discussion}

\section{Mode of transport vs. time factor}

The questions were asked about the usages and types of transport with time factor with respect to private and public transport to reach their destinations as shown in Figure 2 and Table 3.

The data reveals that $52.121 \%$ of public vehicle and $67.515 \%$ of the private own vehicles users spend 15-20 minutes to reach their destinations. $46.666 \%$ of public vehicle and $32.418 \%$ of the private own vehicles users spend 30-40 minutes to reach their destinations. $1.212 \%$ of public vehicle users spend more than 40 minutes to reach their destinations as shown in Figure 2, moreover, $65.553 \%$ of people who keep the private own vehicles, $72.929 \%$ of private own vehicle face traffic problem as shown in Figure 3.

\section{Encroachment and parking space}

The questions were asked about the encroachment in front of their houses or found in their areas as shown in Table 4.

The data shows that the $81.458 \%$ respondents face the encroachment in their areas, whereas, $63.33 \%$ of the respondents do not have the enough parking space as shown in Figure 4.

\begin{tabular}{|c|c|c|c|c|c|}
\hline \multirow{2}{*}{\multicolumn{3}{|c|}{ The area of your House is }} & \multicolumn{2}{|c|}{$\begin{array}{l}\text { Did you migrate from } \\
\text { other areas to settle } \\
\text { in Latifabad }\end{array}$} & \multirow{3}{*}{$\begin{array}{c}\text { Total } \\
5\end{array}$} \\
\hline & & & Yes & No & \\
\hline \multirow{4}{*}{$\begin{array}{l}40-80 \\
\text { sqyds }\end{array}$} & \multirow{3}{*}{$\begin{array}{c}\text { How many } \\
\text { family members } \\
\text { do you live at } \\
\text { home }\end{array}$} & $2-4$ & 1 & 4 & \\
\hline & & $5-7$ & 8 & 14 & 22 \\
\hline & & 8 or more & 6 & 15 & 21 \\
\hline & \multicolumn{2}{|l|}{ Total } & 15 & 33 & 48 \\
\hline \multirow{4}{*}{$\begin{array}{l}120-150 \\
\text { sqyds }\end{array}$} & \multirow{3}{*}{$\begin{array}{c}\text { How many } \\
\text { family members } \\
\text { do you live at } \\
\text { home }\end{array}$} & $2-4$ & 17 & 22 & 39 \\
\hline & & $5-7$ & 34 & 72 & 106 \\
\hline & & 8 or more & 28 & 65 & 93 \\
\hline & \multicolumn{2}{|l|}{ Total } & 79 & 159 & 238 \\
\hline \multirow{4}{*}{$\begin{array}{c}200 \text { sqyds } \\
\text { or more }\end{array}$} & \multirow{3}{*}{$\begin{array}{c}\text { How many } \\
\text { family members } \\
\text { do you live at } \\
\text { home }\end{array}$} & $2-4$ & 4 & 21 & 25 \\
\hline & & $5-7$ & 26 & 55 & 81 \\
\hline & & 8 or more & 23 & 64 & 87 \\
\hline & \multicolumn{2}{|l|}{ Total } & 53 & 140 & 193 \\
\hline \multirow{4}{*}{ Total } & \multirow{3}{*}{$\begin{array}{c}\text { How many } \\
\text { family members } \\
\text { do you live at } \\
\text { home }\end{array}$} & $2-4$ & 22 & 47 & 69 \\
\hline & & 5-7 & 68 & 141 & 209 \\
\hline & & 8 or more & 57 & 144 & 201 \\
\hline & \multicolumn{2}{|l|}{ Total } & 147 & 332 & 479 \\
\hline
\end{tabular}

Table 2: Living criteria of Latifabad residents.

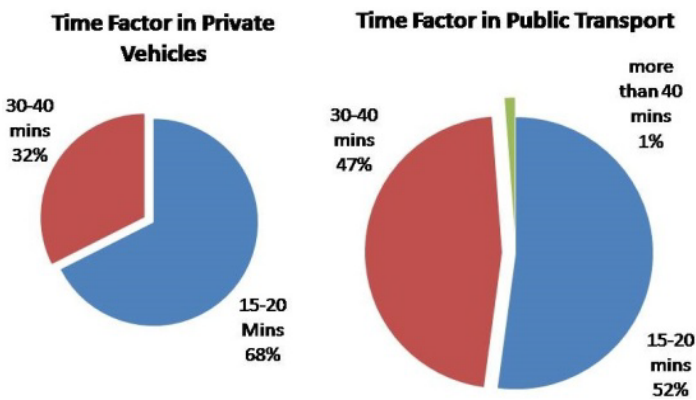

Figure 2: Mode of transport vs. time factor.

\begin{tabular}{|c|c|c|c|c|c|c|}
\hline \multicolumn{3}{|c|}{$\begin{array}{l}\text { Do you find the traffic problem in your } \\
\text { area? }\end{array}$} & \multicolumn{3}{|c|}{$\begin{array}{l}\text { How much time do the } \\
\text { road tracks take to reach } \\
\text { workplace from your } \\
\text { home? }\end{array}$} & \multirow{3}{*}{\begin{tabular}{|l|} 
Total \\
134 \\
\end{tabular}} \\
\hline & & & \multirow{2}{*}{$\begin{array}{c}15-20 \\
\text { mins } \\
63\end{array}$} & \multirow{2}{*}{$\begin{array}{c}30-40 \\
\text { mins } \\
69\end{array}$} & \multirow{2}{*}{\begin{tabular}{|c|}
$\begin{array}{c}\text { more than } \\
\mathbf{4 0} \text { mins }\end{array}$ \\
2 \\
\end{tabular}} & \\
\hline \multirow{3}{*}{ Yes } & \multirow{2}{*}{$\begin{array}{l}\text { What kind of } \\
\text { transport do you } \\
\text { use for your daily } \\
\text { out back? }\end{array}$} & $\begin{array}{l}\text { Public } \\
\text { transport }\end{array}$ & & & & \\
\hline & & $\begin{array}{c}\text { Private } \\
\text { vehicles }\end{array}$ & 151 & 78 & 0 & 229 \\
\hline & \multicolumn{2}{|l|}{ Total } & 214 & 147 & 2 & 363 \\
\hline \multirow{3}{*}{ No } & \multirow{2}{*}{$\begin{array}{l}\text { What kind of } \\
\text { transport do you } \\
\text { use for your daily } \\
\text { out back? }\end{array}$} & $\begin{array}{l}\text { Public } \\
\text { transport }\end{array}$ & 23 & 8 & - & 31 \\
\hline & & $\begin{array}{l}\text { Private } \\
\text { vehicles }\end{array}$ & 61 & 24 & - & 85 \\
\hline & \multicolumn{2}{|l|}{ Total } & 84 & 32 & - & 116 \\
\hline \multirow{3}{*}{ Total } & \multirow{2}{*}{$\begin{array}{l}\text { What kind of } \\
\text { transport do you } \\
\text { use for your daily } \\
\text { out back? }\end{array}$} & $\begin{array}{l}\text { Public } \\
\text { transport }\end{array}$ & 86 & 77 & 2 & 165 \\
\hline & & $\begin{array}{c}\text { Private } \\
\text { vehicles }\end{array}$ & 212 & 102 & 0 & 314 \\
\hline & \multicolumn{2}{|l|}{ Total } & 298 & 179 & 2 & 479 \\
\hline
\end{tabular}

Table 3: Mode of transport vs time factor.

\section{Usage of transport}

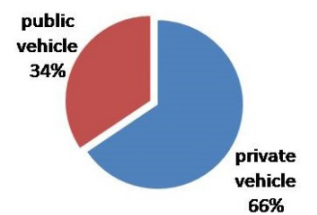

Traffic Problem in Private Vehicles

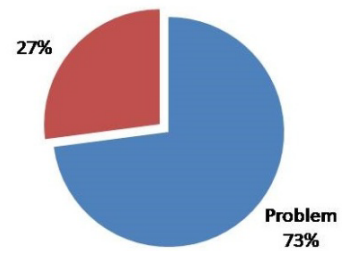

$73 \%$
Figure 3: Mode of transport facing problem.

\begin{tabular}{|c|c|c|c|}
\hline $\begin{array}{c}\text { Do you find the } \\
\text { encroachments of houses in } \\
\text { your area? }\end{array}$ & \multicolumn{2}{|c|}{$\begin{array}{c}\text { Do you find enough space for } \\
\text { parking in your area? }\end{array}$} & \multirow{2}{*}{ Total } \\
\cline { 2 - 3 } & Yes & No & \\
\hline Yes & 141 & 250 & 391 \\
\hline No & 35 & 54 & 89 \\
\hline Total & 176 & 304 & 480 \\
\hline
\end{tabular}

Table 4: Encroachment and parking space area.
Encroachment Level

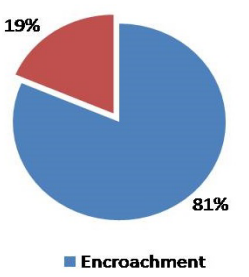

Figure 4: Encroachment and parking space.

\section{Satisfaction index of physical and functional activities}

Average satisfaction index was carried out to find out the level of satisfaction by two points as" satisfied" and "dissatisfied" by the formula of YIS (Yeh's index of satisfaction) as done by Neelum and Abbas [31]. The following formula is used to compute satisfaction index as Equation 


\begin{tabular}{|c|c|c|c|c|}
\hline S. no. & Activity & Satisfied & Unsatisfied & Satisfaction index \\
\hline 1) & Housing availability & 231 & 249 & -3.75 \\
\hline 2) & Traffic problem & 116 & 364 & -51.66 \\
\hline 3) & Other routes availability & 299 & 181 & 24.583 \\
\hline 4) & Shops near to area & 400 & 80 & 66.666 \\
\hline 5) & $\begin{array}{l}\text { Shops and commercial } \\
\text { fulfillment }\end{array}$ & 327 & 153 & 36.25 \\
\hline 6) & Education level & 255 & 225 & 6.25 \\
\hline 7) & Social problems & 138 & 342 & -42.5 \\
\hline 8) & Enough space for parking & 176 & 304 & -26.66 \\
\hline 9) & Traffic noise & 150 & 330 & -37.5 \\
\hline 10) & Encroachment & 89 & 391 & -62.9166 \\
\hline 11) & Parks available & 232 & 248 & -3.333 \\
\hline 12) & Conversion of parks & 269 & 211 & 12.083 \\
\hline 13) & Street furniture & 36 & 444 & -85 \\
\hline 14) & Health problems & 208 & 272 & -13.333 \\
\hline 15) & Usages of utilities properly & 220 & 260 & 8.333 \\
\hline 16) & Political influences & 229 & 251 & -4.583 \\
\hline 17) & Land mafia & 191 & 289 & -20.4166 \\
\hline
\end{tabular}

Table 5: Satisfaction index of physical and functional activities.

$$
\text { YIS }=\frac{\text { Satisfied }- \text { dissatisfied }}{\text { Total respondents }} \times 100
$$

It is easily shown in the Table 5 that there is a much level of dissatisfaction for Housing availability, traffic problem, social problems, enough space for parking, traffic noise, encroachment, parks availability, conversion of parks, street furniture, health problems, usages of utilities, political influences and land mafia involving in land conversions from different attributes to built ups or within built ups classifications as residential to commercial etc.

The education level of standard got the 50\%-50\% of both satisfaction and dissatisfaction level, where as other Routes availability, shops near to area, and shops and commercial fulfillment got much satisfaction level.

The average satisfaction index from this analysis found out to be -41.1431 , which shows a highly dissatisfaction level of Latifabad residents, so, there is a lot of need to improvement and implementing strict policies to get over these issues. Table 5 presented the satisfaction index of physical and functional activities.

The main cause of sprawl is the rapid urban growth, which is in practice by doing the major violation of byelaws. The situation is going to be dangerous as the transformation is taking place. The increased urbanization may have various negative impacts on physical and functional activities, basic infra structure, energy, use and economic development.

\section{Conclusion}

In many cases, definitions are based on implicit value statements that make the concept questionable for understand in scientific research. The sprawl is dealt with qualitative and quantitative measures of urban sprawl. Various attempts of measuring urban sprawl are formulated in the literature.

The qualitative data was gathered and formulated results based on living criteria, transportations with time factors, encroachments, availability of various services in their existing residential units of the people lives in Latifabad, and found satisfactory and unsatisfactory indexes.
It is estimated that $30.688 \%$ has a migration level that shows that $69.311 \%$ of the Latifabad town is the permanent residents. There is a ratio of $65.553 \%$ of people who keep the private own vehicles, and $72.929 \%$ of private own vehicle face traffic problem. The $81.458 \%$ respondents face the encroachment in the areas, whereas, $63.33 \%$ of the respondents do not have the enough parking space.

The average satisfaction index from this analysis found out to be -41.1431 , which shows a highly dissatisfaction level of Latifabad residents, so, there is a lot of need for improvement and implementing strict policies to get over these issues.

\section{Recommendations}

Urban sprawl is noticeably a huge problem in Latifabad nowadays and it needs to be fixed before it grows to such a point of severity that it cannot be fixed, stopping urban sprawl would mean stopping the development of barren lands around city areas completely, which cannot occur with the increase in population of Latifabad.

Although, the problem of urban sprawl illustrate no signs resolving itself in future, if the insight of the suburbs can be changed, there can be the some of the above mentioned ways to solve the issues. After all, the people are the main ones who can make a change when it comes to restrictive suburban expansion to solve even greater issues, such as pollution, health problems, and the crumbling infrastructure.

Urban sprawl can only be slowed down by achieving the Sustainable strategy in order to recommend appropriate policy and management options.

An ideal sustainable strategy can be envisioned as that in terms of development along with diversity, which should be compact and offer array of mixed zones or land uses supported by provisions of sustainable mass transit system, should be energy efficient by means of innovative technology relaying on solar energy and promote ecological protection through greening.

The other strategies are designed as follows:

1. To make people aware of the problem, anything to advertise the problem and raise awareness, would make people notice the amount of harm they are causing by developing such large areas of animal/natural habitat.

2. Another way is to enforce population control. The main cause of urban sprawl is Latifabad's (Currently most populated Taluka in Hyderabad District) increasingly large population. As there are so many people living here, as the population rises, and people move,

3. New developments must be created to suit their needs. Latifabad has to aim for a happy medium. Not too many people, not too few.

4. A third way to slow down urban sprawl is to enhance the use of new technology to facilitate more people to be able to work from home. Currently, people are dependent on accessing workplaces and public services offered only by a large city. There can be an incentive to live near the city because of the perks that the city offers its inhabitants.

\section{References}

1. Bhatta Ba, Saraswati S, Bandyopadhyay D (2010) Urban sprawl measurement from remote sensing data. App Geography 30: 731-740.

2. Ba B (2010) Analysis of urban growth and sprawl from remote sensing data Springer Science \& Business Media, Berlin, Germany. 
Citation: Yar SA (2017) Study of Urban Sprawl and its Social and Environmental Impacts on Urban Society in Latifabad Town, Hyderabad, Pakistan. J Civil Environ Eng 7: 290. doi: 10.4172/2165-784X.1000290

3. El-Garouani, Abdelkader M, David J, El-Garouani S, Knight J (2017) Analysis of urban growth and sprawl from remote sensing data: Case of Fez, Morocco. Int Jof Sustain Built Environ 6: 160-169.

4. Datt SK (1985) Urban development in the metropolitan shadow: A case study from Haryana: Stosius Inc/Advent Books Division.

5. Sanyal S (2008) The Indian renaissance: India's rise after a thousand years of decline: World Scientific Publishing Company, Singapore.

6. Tak RP (2012) Townships for sustainable cities. Procedia Soc Behav Sci 37: 417-426.

7. Dimpal V (2012) Urbanization and solid waste management in India: Present practices and future challenges. Procedia Soc Behav Sci 37: 437-447.

8. Stefan B, Philip O, Ray H, Annegret H, Sigrun K, et al. (2007) Splintering urban populations: Emergent landscapes of reurbanisation in four European cities. Urban Stud 44: 651-677.

9. Julia J, Dirk H (2014) New urban living and mobility. Transport Res Procedia 1: 142-153.

10. Ah GA, Maryamsadat $H$, Houshmand ME (2016) The status of urban and suburban sprawl in Egypt and Iran. GeoScape 10: 1-15.

11. Johannes FJ (2005) The importance of land-cover change in simulating future climates. Science 310: 1674-1678.

12. Houghton RA, House JI, Pongratz J, Van Der Werf, GR DeFries, et al. (2012) Carbon emissions from land use and land-cover change. Biogeosciences 9 : 5125-5142.

13. Jain Atul K, Xiaojuan Y (2005) Modeling the effects of two different land cove change data sets on the carbon stocks of plants and soils in concert with $\mathrm{CO}_{2}$ and climate change. Global Biogeochem Cycles 19.

14. Bo T, Hanqin T, Guangsheng C, Wei R, Chaoqun L, et al. (2013) Terrestria carbon balance in tropical Asia: Contribution from cropland expansion and land management. Global Planetary Change 100: 85-98.

15. Hanqin T, Kamaljit B, Tao B, Vinay DK (2014) History of land use in India during 1880-2010: Large-scale land transformations reconstructed from satellite data and historical archives. Global Planetary Change 121: 78-88.

16. Hanqin T, Guangsheng C, Chi Z, Mingliang L, Ge S, et al. (2012) Century-scale responses of ecosystem carbon storage and flux to multiple environmental changes in the southern United States. Ecosystems 15: 674-694.
17. Linda A, Daniela C, Giovanna P, Marian SE, Massimo V (2014) Urban spraw scatterplots for Urban Morphological Zones data. Eco Indicators 36: 315-323.

18. Paul I, lan M (2004) Managing the environmental impacts of land transport: Integrating environmental analysis with urban planning. Sci Total Environ 334 47-59.

19. William Y, Darrell B (1996) Modelling the environmental impact of changes in urban structure. Computers, environment and urban systems 20: 313-326.

20. Helena M (2012) Urban compaction or dispersion? An air quality modelling study. Atmospheric Environment 54: 60-72.

21. Russell BL (1995) Who will feed China? Wake-up call for a small planet (Vol. 6): WW Norton \& Company, USA.

22. López M, Mitchell AT, Thomlinson JR (2001) Urban expansion and the loss of prime agricultural lands in Puerto Rico. Ambio: A Journal Human Environ 30: 49-54.

23. Fraser HJ (2001) Half a century of cropland change. Geographical Rev 525-543.

24. Karen SC, Kaufmann Robert K, Woodcock CE (2000) Landsat reveals China's farmland reserves, but they're vanishing fast. Nature 406: 121.

25. Minghong T, Xiubin L, Hui X, Changhe $L$ (2005) Urban land expansion and arable land loss in China-a case study of Beijing-Tianjin-Hebei region. Land Use Policy 22: 187-196.

26. David TM (2001) Land-use dynamics beyond the American urban fringe. Geographical Rev 91: 544-564.

27. David TM (2004) Placing exurban land-use change in a human modification framework. Front Ecol Environ 2: 139-144.

28. Fengming X, Hong HS, Keith CC, Yuanman H, Xiaoqing W, et al. (2012) The potential impacts of sprawl on farmland in Northeast China-Evaluating a new strategy for rural development. Landscape Urban Plann 104: 34-46.

29. Muhammad MZ, Hyun RJ (2014) The compact city concept in creating resilient city and transportation system in Surabaya. Procedian Soc Behav Scie 135: 41-49.

30. Robert KV, Morgan Daryle W (1970) Determining sample size for research activities. Edu Psycho Measurement 30: 607-610.

31. Neelum BAN, Abbas AG (2016). Socio-cultural value of public open spaces with Hamchas in Dera Ghazi Khan City, Pakistan Mehran University Research. J Engineering Technol 35: 181-188. 